\title{
Reflections on Domestic Violence During the Movement Control Order: Case Study Evidence from Media Reports
}

\author{
Adam Andani Mohammed, \\ Social Work Studies, \\ Faculty of Social Sciences and Humanities, \\ Universiti Malaysia Sarawak, Kota Samarahan 94300 \\ Md. Sayed Uddin (Corresponding Author) \\ Sociology and Social Anthropology, \\ Faculty of Social Sciences and Humanities, Universiti \\ Malaysia Sabah, Jalan UMS, 88400, \\ Kota Kinabalu, Sabah, Malaysia \\ E-mail: sayed@ums.edu.my \\ Abdallah Mpawenimana Saidi, \\ International Studies, \\ Faculty of Social Sciences and Humanities, \\ Universiti Malaysia Sarawak, Kota Samarahan 94300
}

Received: Jan. 7, $2021 \quad$ Accepted: Feb. 1, $2021 \quad$ Online published: Feb. 17, 2021

doi:10.5296/ijhrs.v11i1.18309～URL: https://doi.org/10.5296/ijhrs.v11i1.18309

\begin{abstract}
The study investigates the incidence of domestic violence as reported by the press under the Movement Control Order MCO during the pandemic. The study also discussed how of issues of domestic violence can be handled now and during future pandemics. Empirical evidence used in this study is based on secondary data and qualitative analysis technique adopted to
\end{abstract}


assess issues of domestic violence. To get relevant data, Google Scholar was used as a tool to access the major databases provided by Springer, IISTE, Tailor and Frances, Emerald, Elsevier, Sage and others. Data were obtained from newspaper articles and news articles from various online news outlets as the only source to access data of incidence of domestic violence in Malaysia during the lockdown. Results indicate a slight decrease in calls on domestic violence immediately after the MCO was implemented on March 18. It is found that the decrease was due to the fact that survivors or victims were trapped with the abusers and could not seek help or escape. The study further found that organizations attending to domestic violence cases reported a serious increase in number of abuse cases in Malaysia in the second week of the MCO thus between 18 and 31 March. The findings are intended to contribute to the narratives on violence against women now and during future disease outbreaks. It may also assist in the future improvement of the provision of services and interventions for victims of domestic violence during pandemic.

Keywords: social media, perpetrators, shelter, coronavirus, vulnerability, discrimination

\section{Introduction}

As the pandemic intensified across the globe, countries have adopted measures like physical distancing, self-quarantining, social distancing among others to slow the spread of the virus for the purpose of containment. As a result, the world witnessed a spike in the number of domestic violence $^{1}$ cases following the Movement Control Order (MCO) imposed by various countries due to COVID-19. Even before the pandemic, a population study conducted around the world by the World Health Organization (WHO) found 10 to $69 \%$ of women of being physically abused by a spouse at home in some point in their lives (Othman \& Adenan, 2008). Considering the seriousness of abuse in recent times, the United Nations Secretary General, Antonio Guterres is reported to have said that the COVID-19 self-quarantine inflicts severe consequences on millions of women around the world (UN 2020). He Twitted "I urge all governments to put women's safety first as they respond to the pandemic" (The United Nations Secretary General António Guterres on Twitter cited in Taub 2020). Invariably, the extreme danger women face when trapped in the same house with abusive men can be unimaginable. Empirically, domestic violence before and during COVID-19 may include but not limited to threatening or other violent behaviors within families that may be physical, sexual, psychological, or economic, and can include child abuse and spouse violence (Othman \& Adenan 2008; Serrata et al, 2020; Peterman et al, 2020; van Gelder et al, 2020). It is clear that women are increasingly at risk of violence against them when they are trapped with the perpetrators without any security guaranteed or any support available for them. Scholars revealed that the most extreme consequence of mental instability due to domestic violence can result in suicidal thoughts (Islam et al, 2018; Mamun \& Griffiths 2020).

\footnotetext{
${ }^{1}$ Domestic violence refers to a range of abuse taking place within the house and encompasses intimate partner violence perpetrated by a current or ex-partner. The phrase, 'domestic violence' is used because of its popularity in the media as such it is used in place of intimate partner violence in this review. Multiple terms like family violence, domestic disputes, partner abuse, spouse abuse, wife abuse, wife battering, battered wives, battered women and intimate partner violence are used interchangeably to explain domestic violence in most literature. See: Backes et al. (2020). The criminal justice system response to intimate partner stalking: a systematic review of quantitative and qualitative research. Journal of Family Violence, $1-14$.
} 
The prevailing patriarchal cultural practices in the daily life of women in most countries led to the institutionalization of domestic violence with great consequences and impunity. As shown, the operation of MCO may encourage violence as the abuse is about widespread emotional violence like insults, intimidation, humiliation and threat to harm as well as controlling behavior (Bott et al, 2012; Bradbury-Jones \& Isham 2020). As ways of enforcement, MCO encourages isolation from friends and relatives as well as restricting movement all the time and physical contacts with family, friends and general public which endangers women's life. The reasons for COVID-19-related domestic violence include the fear of infection, the fear of passing the virus onto others so the incidence of abuse was a consequence of quarantine, isolation and economic hardship (Dsouza et al, 2020; Goyal et al, 2020; Mamun \& Griffiths 2020; Mamun \& Ullah 2020). The forms of violence perpetrated against women before and during these trying times of MCO include physical and sexual or both may lead to severe emotional and physical damages like cuts, burns, loss of teeth, sadness, insomnia among others (Migueles, 2018). Studies from over 80 countries suggest that 1 in 3 women in a relationship has experienced physical and/or sexual violence by a spouse at some point in their lives and in most cases endure multiple and compounding forms of violence in emergency settings like the current pandemic (John et al., 2020). The most unfortunate part of the plight of victims is that shelters are also reported to have been making hard decisions and refusing new clients who do not have proof of testing negative to avoid spreading the virus to the existing clients. The press and reports (Nigam 2020; Nieto et al, 2020; Campbell 2020; Peterman et al, 2020; van Gelder et al, 2020; Berenice 2020; Reuters 2020; Knowles 2020; Kelly \& Morgan 2020; Usher et al, 2020; John et al, 2020; Graham-Harrison et al, 2020) around the world indicate the threat post by MOC cut across both developed and developing societies.

As the carnage of the Coronavirus (Covid-19) continues, certain measures are being implemented to slow the spread of the virus. Several countries, including Malaysia encouraged the citizenry to observe social distancing and travel restrictions to reduce the transmission of the disease. This study therefore explores the incidence of domestic violence and its occurrence to offer wider understanding of the effects of this pandemic. The study presents eight cases in chronological order of reports of incidence of violence during the peak (March - April) of the MCO in Malaysia.

\section{Methodology}

This narrative study focused on articles available in English and adopted secondary data analysis approach. Data were taken from press reports online, thus from newspaper articles and news articles from various online news outlets as well as papers published in areas of domestic violence in relation to COVID-19. The search was done using Google scholar.

The paper is primarily based on secondary data and qualitative analysis technique adopted to assess issues of domestic violence during the MCO in Malaysia. Extensive and relevant literature was gathered from articles, valid sources from the internet news portals that keep up with the latest development in relation to domestic violence in the country. Therefore, the valuable source of data for the current study is extracts from the press that shed lights on how women are trapped with the abusers at home. The study engaged a deductive search of media 
articles available in Malaysia via online news websites published in March and April 2020 during the MOC. The search involved reading to identify reports that indicate COVID-19 related to the rise in incidence of domestic violence. A sample of the media article were collected to refine the information and to generate representative cases on issues about abuse of women during the MCO.

All the authors consulted with one another throughout the analysis of the articles. The authors also discussed and reviewed each other's portion of the paper and what they found to support validity and reliability of the analysis. The researchers settled on descriptive cases as most appropriate to respond to the research question to describe recent incidence of domestic violence under the Movement Control Order MCO in Malaysia. The data collected through multiple sources and varied interpretation was analyzed in line with the research objectives. This involved reading and re-reading articles to locate consistent information to support the objectives of the review. The main cases were derived from the data after several readings and analysis. These cases were based on the appearance in the secondary data and information obtained from the literature.

The limitation of the study is the fact that it is based on online press report, articles and not that of women's voices or personal narratives or face-to-face presentation of testimonies for that matter it is not based on intense empirical techniques. Therefore, the basic features of the study are to offer a glimpse of domestic violence occurrences in the country rather than seek generalization.

\section{Literature Review}

Malaysia is part of the Convention on the Elimination of All Forms of Discrimination against Women (CEDAW) at the international and regional level. As such, domestic violence has been recognised as a social problem in the country since the Convention on the Elimination of All Forms of Discrimination against Women (CEDAW) in 1979. The country put various strategies, campaigns and legislations in place to tackle the problem of domestic violence. For instance, the amendments introduced by the government include the Domestic Violence (Amendment) Act 2012 (Malaysia, Act AA1414) and Domestic Violence (Amendment) Act 2017 (Act A1538) to the Domestic Violence Act 1994 (Malaysia, Act 521) (known as the DVA 1994) all aimed at dealing with the definition and meaning of domestic violence in Malaysia. As recent as 2017, the country put in place various reforms to provide better protection for women and children. Mention can be made of the Sexual Offences against Children Act 2017 (SOAC), the Legal Aid (Amendment) Act 2017 and the Domestic Violence (Amendment) Act 2017 were passed and implemented (WCC, 2019). Invariably, when a crime is committed under this, the victim is supposed to lodge a police report for action to be taken against the perpetrator (Backes et al., 2020). If the crime of domestic violence is established, then the victim is referred to the One Stop Crisis Centre (OSCC) at the Emergency and Trauma Unit in any government hospital for a medical examination to ensure the victim gets appropriate medical care and to collect evidence of the crime (WCC, 2019). All of the strategies, campaigns and legislations are put in place to protect women against all forms of abuse at all time, during emergency situations like the MCO not 
exception.

However, a cross section (women) of the citizens cannot find any safety during MCO as most of them are trapped in the home with a violent perpetrator at a time of limited contact with outsiders (Campbell, 2020). Confinements in physical space, socioeconomic problems and health shocks due to the havoc caused by the pandemic and measures like quarantine and social distance may increase stress levels among couples and may lead to domestic violence against women. Studies before the pandemic revealed that about $39 \%$ of women above 15 years of age in Malaysia were estimated to have been physically assaulted by their spouses (Othman \& Adenan, 2008). The Women and Family Development Ministry and NGOs attending to domestic violence cases reported the serious increase in numbers of domestic violence in Malaysia. This may be attributed to the lockdown that restrict the citizens from leaving their homes except to buy food, in emergencies or to access health care which make women more susceptible to domestic violence. Apart from the restrictions, women in patriarchal societies are already reluctant to report cases of abuse to the police for the fear of torture from the husband's people in case the husband is arrested. In recent times, there are reports (Campbell 2020; Peterman et al, 2020; van Gelder et al, 2020; Usher et al, 2020; Tashny 2020) of increase in number of calls for rescue from abuse in the country following the MCO. It is obvious that MCO and COVID-19 may increase vulnerability and reduced options for support that women need.

There are other agencies and organisations that complement the efforts of the government and departments responsible for the welfare of women and children during the period. The most notable shelters and centers in Malaysia which stand out for the protection of women against all form of violence include the Women's Aid Organisation WAO, WCC Penang, KANITA among others provide shelter and other services for victims of domestic violence. The goals of these centers include awareness creation, promote advocacy to end violence against women and provide capacity-building for the victims of violence. The locations of these shelters, for instance, are kept confidential to avoid potential aggression or endangerment of the women. This is to promote the autonomy of the women within a culture of proper treatment. The women are allowed to stay in these shelters for at least up to three months. As part of their contribution, the Women's Aid Organisation of Malaysia (WAO) was among the first to conduct empirical study and analysis of domestic violence in 1995. This enticed researchers (Othman \& Mat Adenan 2008; Wong \& Othman 2008; Phillips et al, 2006; Abdul-Ghani 2014) as well as centers (Women's Aids Organisation of Malaysia (WAO); WCC, Penang, the Women's Development Centre (KANITA)) to investigate issues of domestic violence in the country before and during the MCO.

Domestic violence in Malaysia is not exception, as reports around the world indicate the threat post by MOC cut across both developed and developing societies. As indicated, anecdotal evidence from the UK, Russia, France, United States, China, Brazil, and Australia indicates increases in intimate partner, women, and children violence due to isolation and quarantine (Nieto et al, 2020; Campbell 2020; Peterman et al, 2020; van Gelder et al, 2020). It is reported that just three weeks after the social distance measure was announced in Mexico, domestic violence related calls to the 911 emergency number increased by $60 \%$ and the federal authorities estimated that violence against women had gone up between $30 \%$ to $100 \%$ 
(Nieto et al., 2020). In India, the calls received by the DCP in Delhi jumped from 1000 to 1200 per day as compared to 900-1000 calls received before the lockdown. It is estimated that around 2500 cases reported from Delhi alone during the lockdown (Nigam, 2020). Thus, 34 percent increase in calls was received pertaining to domestic violence on the helpline numbers per day within a month. Reuters revealed an increase in domestic violence complaints in France from a $32 \%$ to $36 \%$ following the implementation of self-isolation and quarantine measures (Usher, Bhullar, Durkin, Gyamfi, \& Jackson, 2020; Reuters News Agency 2020). The reports from Australia revealed that the police in some parts of the country reported a 5\% increase in domestic violence call-outs (Kagi, 2020) and that Google reported a $75 \%$ increase in Internet searches for domestic violence support (Poate, 2020). Similar reports of increases in domestic violence incidents range between $21 \%$ to $35 \%$ in individual states in the United States of America (Wagers, 2020). The UK has also registered concerns about increase in domestic violence (Bradbury-Jones \& Isham, 2020). For instance, the UK National Domestic Abuse Hotline revealed 25\% increase in calls as well as record some domestic violence related death after the implementation of the stay-at-home order (Knowles 2020; Kelly \& Morgan 2020; Usher et al, 2020). Domestic violence prevention groups in South Africa also experienced increases in new cases as restrictions are being imposed to tackle the COVID-19 (John et al, 2020). The above figures show that domestic violence occurred in nearly all parts of the world during the pandemic.

\section{Findings}

The Covid-19 crisis can result in frustration, stress and risk factors for domestic violence like job lose, limited income and resources since limited socioeconomic support may likely worsen abuse in the home. It is obvious that the accumulation of stressful events coupled with inadequate socioeconomic support due to MCO may also increase the risk for abuse. It is also significant to note that victims of domestic violence may not have access to online phone support following the control tactics often used by abusive partners. This systematic review looked at previous research that examined the incidence of domestic violence during the pandemic. The analysis revealed some interrelated cases in chronological order from the press as presented below.

\subsection{Media Reports of Domestic Violence During the MCO in Malaysia}

The dangers and risk of violence against women in the context of the coronavirus disease, Covid-19, are worse than before. The disease containment measures like physical distancing, and self-quarantines are well-established measures and essential for reducing risk of getting COVID-19. McLaren et al. (2020) stated that war, natural disaster or disease outbreak alter the power relations between women and men thus drawing upon women's vulnerabilities. With these vulnerabilities, there are likely consequences for women as they are trapped with the abusers thus considering the impact of violence in the home during the MCO. Investigation into online portals captured interesting captions that suggest that domestic violence during the lockdown was really a concern for many as shown in the following cases.

Case 1 (March 27, 2020: Source - Darshini Kandasamy 27 Mar 2020) this article suggested the severity of the abuse as the caption in Malaysiakini by Darshini (2020) reads Silent cries: 
Fear mounts over likely spike in domestic abuse, severity during MCO. It is reported that the Women's Aid Organization WAO and police told Malaysiakini that they noticed a slight decrease in calls on domestic violence since the MCO was implemented on March 18. They opined that the decrease might be due to the fact that survivors or victims are trapped with the abusers and are unable to seek help or escape. With this assumption, it was assumed that WAO is expected to witness increase in report of cases once the MCO is lifted only then victims or survivors will be able to seek for help with ease. On the other hand, WAO is reported to have received an average of 10.5 calls and enquiries per day between March 1 and 17. However, between March 18 and 31, it received reports of 12 cases daily. Similarly, the Women's Centre for Change (WCC) in Penang also extended period of counseling for women in crisis, especially domestic and sexual violence cases during the MCO. Reports indicated that the WCC received 14 phone calls in the first week of the MCO (March 18 to 24) but that number increased to 36 cases in the second week (March 25 to 31) (Malaysiakini, 2020). The number of new domestic violence cases reported by the One-Stop Crisis Centres (OSCCs) of Penang hospitals also tripled, from two cases to six cases in the second week. The Programme and Operations manager of All Women's Action Society (Awam) also said issues of domestic abuse exacerbated during the MCO due to the inability of survivors to socialize or leave their home freely. (Source: https://www.malaysiakini.com/news/517065)

Case 2 (March 30 2020: Source - Athira Nortajuddin 30 March 2020) Another interesting article title Virus lockdown causing rise in domestic abuse by Athira Nortajuddin 30 March 2020 revealed a rise in calls. According to Athira, the local media reported that a week after Malaysia's MCO was enforced the Talian Kasih hotline had an increase in number of calls and reports of abuse as of 26 March. Besides, the communications department revealed that 1,893 calls to the helpline had been recorded ever since the partial lockdown started. By implication, the number of calls has increased by 57\% during the MCO. Considering the seriousness of abuse, the Talian Kasih hotline which was briefly suspended was reintroduced to provide counselling and assistance to women experiencing abuse and are in need of protection. The Executive director of Sisters in Islam (SIS) - an organisation committed to women's rights criticized the suspension of Talian Kasih 15999 at a time when women may need help the most. Based on this criticism, the Talian Kasih hotline was made to operate everyday and 24 hours each day. (Source: https://theaseanpost.com/article/virus-lockdown-causing-rise-domestic-abuse)

Case 3 (April 02, 2020: Source - Todayonline 02 April 2020) In an article title Women's group in Malaysia fears rise in domestic violence cases during country's partial lockdown, WAO officer told the Malaysian Insight that before MCO was enforced on March 18, the organization received an average of 77.5 hotline calls and WhatsApp enquiries per week. The figure however decreased to an average of 73 hotline calls and WhatsApp enquiries per week during the restriction period (Todayonline 2020). The Sexual, Women and Child Investigations Division (D11), indicated that the decrease in number of calls does not mean domestic violence is not happening. The Malaysiakini was later on informed that the D11 and WAO worked together to rescue a survivor who was looking to escape her "severe physical abuse" from her husband during the partial shutdown order. With this, the Hotline operation 
hours for WAO have been extended to provide advice and support through the phone and WhatsApp chat (Source: https://www.todayonline.com/world/womens-group/wao.org.my).

Case 4 (April 3, 2020 2020: Source - Tasneem Nazari, 3 April 2020) Domestic Violence Rates in Malaysia Increase under MCO authored by Tasneem Nazari, also filed report on domestic violence situation under the lockdown. Tasneem amplified the information the Women's Aid Organisation (WAO) advocacy officer shared with the Malay Mail that their statistics show a $14 \%$ increase in hotline calls and WhatsApp enquiries on domestic violence since the beginning of the MCO. And that the organisation received an average of 10.5 calls and enquiries per day between 1 and 17 March but the number rose to an average of 12 calls and enquiries a day between 18 and 31 March (Tasneem 2020). This implies that the MCO rules pose predictable grave challenges or a threat to women during the coronavirus lockdowns. Most women staying with their husband at home is not comforting and by implication the MCO has made violence at home more frequent and dangerous as women cannot reach out for help. As increase abuse is bound to happen in emergencies like conflict, economic crisis or during disease outbreaks like COVID-19. (Source: https://www.therakyatpost.com/2020/04)

Case 5 (April 4, 2020: Source - Tharanya Arumugam, 4 April 2020): An article title MCO-linked domestic violence rises by Tharanya (2020) suggested an increase in abuse is linked to MCO. In this article, Tharanya reported that Malaysia has seen a spike in the number of domestic violence cases following the Movement Control Order (MCO) since March 18. The ministry's Talian Kasih hotline had seen a 57\% increase (or 1,893 calls) from women in distress between March 18 and 26. Women's rights groups have also reported a substantial increase in calls (Tharanya 2020). It is obvious that measures like physical distancing, self-quarantine or social distancing might have exacerbated personal and collective vulnerabilities as accessibility and familiar support options are limited. (Source: https://www.nst.com.my/news/exclusive/2020/04).

Case 6 (April 11, 2020: Source - Tashny Sukumaran 11 April 2020) Another caption title In Malaysia, domestic violence spikes amid lockdown to slow coronavirus infections by Tashny also pointed to seriousness of reported abuse cases. Tashny (2020) pointed out that the lockdown that bans Malaysians from leaving their homes except for food, in emergencies or to access health care has left women and children more susceptible to domestic violence and abuse. The reported distress calls to the Women's Aid Organization (WAO) thus, reporting a 44.4\% increase in calls and enquiries between February and March (Tashny 2020). In the northernmost state of Penang, the Women's Centre for Change (WCC) in Penang has reported a fourfold increase in domestic violence-related distress calls, with this period above the monthly average in 2019, said program director of the center (Tashny 2020). (Source: https://www.scmp.com/week-asia/people/article/)

Case 7 (April 12, 2020: Source - Ida Lim 12 April 2020) An article in Malay Mail by Lim entitle Minister advises domestic violence victims to call women's ministry hotline for quick police action also reported the seriousness of abuse during the lockdown. Lim (2020) said that the authorities appeared to acknowledged reports of the rise in abuse cases happening in 
families following the movement control order (MCO). As part of observing movement control order, restaurant services in Malaysia were limited to take-away services as such husbands who smoke, use drugs or drink alcohol were supposed to do that at home thus a possible source of violent behavior. (Source: https://www.malaymail.com/news/malaysia/2020/04/12/).

Case 8 (April 20, 2020: Source - Sheralyn 20 April 2020) Domestic Abuse Has Increased in Malaysia during MCO, But Why is it So Hard for Women to Break Free? In corroboration with earlier reports, Sheralyn stated in the article that the statistics of domestic violence happening in the country ever since the MCO was implemented has increased between February and March 2020. And that the WAO's hotline has seen a 44.4\% increase in calls and enquiries. It is reported that they received 226 calls in January, 250 calls in February and 361 calls in March also reported in MalaysiaKini. This suggests that the rates of violence are on the rise and the challenges of accessibility of services and the ability of women to access these services under the MCO. (Source:https://worldofbuzz.com/domestic-abuse-has-increased-in-malaysia-during-mco-butwhy-is-it-so-hard-for-women-to-break-free/)

\section{Discussion}

The Covid-19 pandemic affects a series of social and economic entities which may lead to domestic violence especially during the MCO. One of the tactics of violent abusers is to isolate the victim which makes covid-19 measures like self-quarantine, social isolation, physical distancing among others dangerous for women as the press reported. According to Taub (2020), domestic abuse is acting like an opportunistic infection, flourishing in the conditions created by the pandemic. With the lockdown in place, women are not able to disclose any ordeal and will therefore continue to be under the control of the abuser. A recent review of the psychological impact of quarantine indicated increased anger, confusion and posttraumatic stress symptoms, as well as evidence of increases in substance use in those subjected to quarantine (Brooks et al, 2020; Humphreys et al, 2020; Mohammed, Uddin, \& Saidi, 2020). A potential increase in domestic violence against women due to spending long periods in self-quarantine alongside their aggressors is eminent and widespread. Taub (2020) observed that domestic violence goes up whenever family members spend more time together even during festive periods and summer vacations. The communication aid like phone is the only means to get in touch with people outside the home for rescue but unfortunately that is the first item to be seized in most cases. As such, it is obvious that women under quarantine and abuse may not have access to the social media, internet or cell phone to reach out for help. As the order implies, social or physical distancing does not allow the victim to reach out to the family, friends or relatives to offer emotional support or the opportunity to escape the abuse. For van Gelder et al. (2020), physical isolation as a government-sanctioned approach has increased cases of domestic violence significantly. Even, when distress calls are made shelters that used to serve as safe havens are reluctant to entertain victims of domestic violence for the fear of getting infected.

The increase in reported cases of abuse is not happening only in one particular location but 
cuts across Malaysia as shown by the press. The surge of distress calls from victims of abuse are being reported across the country since the implementation of the MCO in the countries. The view about domestic violence as family problem does not change even under the current situation. The pandemic may worsen the patterns of coercive behaviour like sexual harassment and financial oppressions that may cause physical injuries, psychological and emotional trauma to the victim. In expressing the dynamics of domestic violence, Abdul Ghani, et al., (2016) revealed that its problems have been identified as occurring across all religions, ethnicities, cultures, ages, societies and economic status. By implication, it may be considered as a significant socioeconomic and public health problem under the current situation as reported in the press. It is obvious that the economic stresses of the pandemic and disruptions of interaction make anger and stress management difficult. According to Humphreys et al. (2020), couples with parental anxiety and stress about financial and existential concerns are likely recipe for temper outbursts, verbal and physical abuse. Most of the online reports observed that victims' inability to access support services may weigh heavily on them and add to their burdens (Nigam 2020; Humphreys 2020). The fear and emotional stress as a result of the lack of support can increase violent behavior, especially within the home during the self-quarantine when the abuser and victim are compelled to stay indoors. Better still, shelter support services and other organisations were supposed to be the lifeline for women under MOC by helping them to deal with domestic violence or abuse. However, the reports suggested that they were not considered as essential services providers which made it difficult for them to operate effectively in responding swiftly to distress calls. As much as quarantine is one of the effective ways to contain the current pandemic, it may also be a deadly trap for the victims of domestic abuse since they are cannot access any support from shelter providers.

In most patriarchal societies, husbands have rights over women as the cultural norm permit the use of physical violence as an acceptable way to discipline a disobedient wife. The subjective definition of disobedience and living under the same roof with one's abuser will definitely generate fear of what might happen to you in the next moment, considering the restrictions under the MCO. In such circumstances, studies indicate how husbands control the thinking of the wife by manipulating her thoughts and through provocation of fear or putting any unjustified mistakes upon her to justify abusive behaviour (Razali, et al, 2018; Olusegun, Olatubosun, Adedokun, \& Abiodun, 2019). The fact that self-quarantine is crucial to the fight against Covid-19 gives the abuser more power to perpetrate violence since all the support nets to the victim are shut which makes it extremely difficult for her to call for help or escape. In the words of Abdul-Ghani, (2014), living in an abusive relationship gradually undermined the women's ability to feel confident in coming forward to deal with the violent situation with appropriate assistance especially in the current situation. Consequently, domestic violence is bound to happen and even escalate during trying times like this since perpetrators have more power and victims less access to their families or less able to get away with the abuse easily due to break down of support services and the social distancing restriction under the MCO. Under normal circumstances, Awang and Hariharan (2011) indicated that domestic violence comes in many forms, such as sexual abuse, threats and intimidation, emotional and social abuse, and financial deprivation all of which are the situation women found themselves. 
Considering crisis situation like that of COVID-19, the victim may be subjected to these abuses in addition to assorted forms of maltreatments likes merciless beatings, verbal abuse, starvation or not allow to use the wash room among others. According to Razali, et al., (2018), the husband perpetrates emotional violence through continuing use of language and means of communication that inflicts extreme sadness and despair on the wife. Other abuses that may be emotional include monitoring of activities, strict rules for behavior and restriction of movement within the home.

The press reports suggested that current pandemic calls for strategic inclusive responses that include women in the development of disaster responses, the control of resources and in making decisions that affect them. Both wives and husbands are struggling to cope with the MCO especially those employed in the informal sectors who stand the chance of losing their income and/or jobs. Hellman and Gwinn, (2017) proposes an emerging camping and mentoring model that can offer an intervention not only for victims and survivors but one with the capacity to generalize to domestic violence at a national level. In talking about disruption of jobs and for that matter income, men invariably bear the brunt of the MCO due to their traditional role as head and breadwinner of the family which lead to frustration and stress and eventual abusive behaviour. In such situations, women become the target on whom frustrations and anger are vented upon. In such situations, socioeconomic interventions are needed to alleviate the fear and suffering of husband in terms of meeting their obligations as expected. Studies has shown that early intervention is essential to prevent negative outcomes and potentially long-lasting problems across lifespan (Huang et al, 2010; Herschell, Scudder, Schaffner, \& Slagel, 2017). Relatively, this becomes the source of violence especially when the man is reminded of his responsibilities in direct or indirect request for money to buy or pay for utilities. Women who live in chaos and fear experience a multitude of negative stressful situations which manifest into potentially negative psychological and behavioral reactions that make life difficult in the absence of strategic intervention (McLaren et al, 2020; Ali \& Pervaiz 2017; Benavides 2015; Mohammed et al, 2020). The husband resorts to violent behavior in an attempt to avoid the perceived shame attached to his inability to meet the obligation as the family head or breadwinner due to the fact that he is out of job as a result of covid-19. In corroboration, studies indicated that family violence during pandemics is associated with factors like economic stress, instability, increased exposure to exploitative relationships, and reduced options for support (Peterman et al. 2020; Usher et al., 2020). It is crucial for authorities to incorporate a gender perspective in the fight against COVID-19 as failure to take any actions to protect women and children will affect their lives now and in the future.

\section{Conclusion}

Families are at home across the globe due to Covid-19 lockdown observing self-quarantine or self-isolation. This measure has exposed and intensified the fear and risk as women are trapped at home with unfriendly figure worse than the virus. Women therefore find themselves in double danger or dilemma as neither outside the house nor inside the home is safe. This time it is not the cultural norm that made women reluctant to talk about physical violence perpetrated by the husband but the movement restriction imposed by nations to slow 
the spread of the pandemic. Abusive husbands get away with the perpetration of violence with impunity because of the inability of women to report them due to fear of getting infected with the virus or arrested for violating MCO or fear of unbearable consequences. Quite apart, the difficulty for women to escape this kind of abusive relationships in current crisis might also be because of the difficulty in moving with children with the fear of getting infected. The incidence of domestic violence during the $\mathrm{MCO}$ is observed to be encompassing as it is prevalent in developed and developing countries and affect children, the poor and the rich in diverse ways. For lack of empirical data, the online news portal assumed that all kinds of abuses would have been perpetrated during the current lockdown and more will be committed if it persisted. If the situation is left unchecked will lead to overwhelming fear for being trapped within the home with the abuser and may bring about unintended consequences. It is also anticipated that the post-pandemic period will witness women and their children suffer the negative repercussion of domestic violence they have gone through. The post-COVID-19 lockdown need authorities and departments responsible for women's welfare to be alert for consequences of domestic violence among members of society. Given the fact there is no vaccine to treat COVID-19 and not sure when the pandemic will end has psychological effects that may lead to more abuse. Therefore, relevant public strategies are needed to minimize domestic violence now and in future.

\section{References}

Abdul-Ghani, M. (2014). Exploring domestic violence experiences from the perspective of abused women in Malaysia (Doctoral dissertation, Loughborough University).

Abdul-Ghani, M., Ahmad, N. A., \& Mohamad, A. (2016). Profiles of Domestic Violence Victims and Perpetrators: A Qualitative Research Perspective. Journal of Advanced Research in Social and Behavioural Sciences, 4(1), 43-50.

Ali, S., \& Pervaiz, F. S. S. J. Z. (2017). Women of North Pakistan in the Line of Domestic Violence. Research on humanities and social sciences, 7(3).

Awang, H., \& Hariharan, S. (2011). Determinants of domestic violence: Evidence from Malaysia. Journal of Family Violence, 26(6), 459-464. https://doi.org/10.1007/s10896-011-9380-6

Backes, B. L., Fedina, L., \& Holmes, J. L. (2020). The criminal justice system response to intimate partner stalking: a systematic review of quantitative and qualitative research. Journal of Family Violence, 1-14. https://doi.org/10.1007/s10896-020-00139-3

Benavides, L. E. (2015). Protective factors in children and adolescents exposed to intimate partner violence: An empirical research review. Child and Adolescent Social Work Journal, 32, 93-107. https://doi.org/10.1007/s10560-014-0339-3

Bott, S., Alessandra G., Mary, G., \& Jennifer A. M. (2012). "Violence Against Women in Latin America and the Caribbean: A comparative analysis of population-based data from 12 countries." Pan American Health Organization; Centers for Disease Control and Prevention. [Online]. 
<https://www.paho.org/hq/dmdocuments/2014/Violence1.24-WEB-25-febrero-2014.pdf> (Consulted: 01/04/2020).

Bradbury-Jones, C., \& Isham, L. (2020). The pandemic paradox: the consequences of COVID-19 on domestic violence. Journal of clinical nursing. https://doi.org/10.1111/jocn.15296

Brooks, S. K., Webster, R. K., Smith, L. E., Woodland, L., Wessely, S., Greenberg, N., \& Rubin, G. J. (2020). The psychological impact of quarantine and how to reduce it: rapid review of the evidence. The lancet, 395(10227), 912-920. https://doi.org/10.1016/S0140-6736(20)30460-8

Campbell, A. M. (2020). An Increasing Risk of Family Violence during the Covid-19 Pandemic: Strengthening Community Collaborations to Save Lives. Forensic Science International: Reports, 100089. https://doi.org/10.1016/j.fsir.2020.100089

Dsouza, D. D., Quadros, S., Hyderabadwala, Z. J., \& Mamun, M. A. (2020). Aggregated COVID-19 suicide incidences in India: Fear of COVID-19 infection is the prominent $\begin{array}{llll}\text { causative } \quad \text { factor. } & \text { Psychiatry } & \text { Research, }\end{array}$ https://doi.org/10.1016/j.psychres.2020.113145

Goyal, K., Chauhan, P., Chhikara, K., Gupta, P., \& Singh, M. P. (2020). Fear of COVID 2019: First suicidal case in India! Asian journal of psychiatry, 49, 101989. https://doi.org/10.1016/j.ajp.2020.101989

Graham-Harrison, E. A., Guifrrida, H. S., \& Ford, L. (2020, March 28). Lockdowns around the world bring rise in domestic violence. Retrieved 23 April 2020, from The Guardian: https://www.theguardian.com/society/2020/mar/28/lockdowns-world-rise-domestic-violence.

Hellman, C. M., \& Gwinn, C. (2017). Camp HOPE as an intervention for children exposed to domestic violence: A program evaluation of hope, and strength of character. Child and Adolescent Social Work Journal, 34(3), 269-276. https://doi.org/10.1007/s10560-016-0460-6

Herschell, A. D., Scudder, A. B., Schaffner, K. F., \& Slagel, L. A. (2017). Feasibility and effectiveness of parent-child interaction therapy with victims of domestic violence: A pilot study. Journal of Child and Family Studies, 26(1), 271-283. https://doi.org/10.1007/s10826-016-0546-y

Huang, C. C., Wang, L. R., \& Warrener, C. (2010). Effects of domestic violence on behavior problems of preschool-aged children: do maternal health and parenting mediate the effects? Children and Youth Services Review, 32, 1317-1323. https://doi.org/10.1016/j.childyouth.2010.04.024

Humphreys K, L., Myint M, T., \& Zeanah, C. H. (2020). Increased risk for family violence during the COVID-19 pandemic. Pediatrics. https://doi.org/10.1542/peds.2020-0982

Islam, M. M., Jahan, N., \& Hossain, M. D. (2018). Violence against women and mental disorder: a qualitative study in Bangladesh. Tropical medicine and health, 46(1), 1-12. https://doi.org/10.1186/s41182-018-0085-x 
John, N., Casey, S., Carino, G., \& McGovern, T. (2020). Lessons Never Learned: Crisis and gender-based violence. Developing world bioethics. https://doi.org/10.1111/dewb.12261

Kagi, J. (2020). Crime rate in WA plunges amid coronavirus social distancing lockdown measures. ABC News Australia. Retrieved on 10th May, 2020 from: https://www.abc.net.au/news/2020-04-08/coronavirus-shutdown-sees-crime-ratedrop-in-wa/1 2132410.

Kelly, J., \& Morgan, T. (2020). Coronavirus: Domestic abuse calls up 25\% since lockdown, charity says. BBC News. Retrieved on 12th May, 2020 from: https://www.bbc.com/

Knowels, M. (2020). Coronavirus lockdown risks murder frenzy - PM sent warning on domestic abuse. The Express. Retrieved on 7th May, 2020 from: https://www.express.co.uk/news/uk/1265912/coronavirus-lockdownmurder-warning-domesti c-abuse-boris-johnson

Mamun, M. A., \& Griffiths, M. D. (2020). First COVID-19 suicide case in Bangladesh due to fear of COVID-19 and xenophobia: Possible suicide prevention strategies. Asian journal of psychiatry, 51, 102073. https://doi.org/10.1016/j.ajp.2020.102073

Mamun, M. A., \& Griffiths, M. D. (2020b). PTSD-related suicide six years after the Rana Plaza collapse in Bangladesh. Psychiatry research, 287, e112645. https://doi.org/10.1016/j.psychres.2019.112645

Mamun, M. A., \& Ullah, I. (2020). COVID-19 suicides in Pakistan, dying off not COVID-19 fear but poverty? - The forthcoming economic challenges for a developing country. Brain, behavior, and immunity. https://doi.org/10.1016/j.bbi.2020.05.028

McLaren, H. J., Wong, K. R., Nguyen, K. N., \& Mahamadachchi, K. N. D. (2020). Covid-19 and Women's Triple Burden: Vignettes from Sri Lanka, Malaysia, Vietnam and Australia. Social Sciences, 9(5), 87. https://doi.org/10.3390/socsci9050087

Migueles, R. (2018). "Millions of women are victims of domestic violence". El Universal. [Online]. Available at: <https://www.eluniversal.com.mx/english/women-domestic-violence/> 01/05/2020).

Mohammed, A. A., Uddin, M. S., \& Saidi, A. M. (2020). Covid-19 And Movement Control Order: Stress and Coping Strategies of Students Observing Self-Quarantine. https://doi.org/10.6007/IJARBSS/v10-i5/7249

Nieto, B. F., Soria, I. Y., \& Bravo, M. A. (2020). Domestic violence in Mexico in times of COVID-19.

Nigam, S. (2020). COVID-19, Lockdown and Violence against Women in Homes. Lockdown and Violence against Women in Homes (April 28, 2020). https://doi.org/10.2139/ssrn.3587399

Olusegun, G. F., Olatubosun, S. M., Adedokun, M. O., \& Abiodun, E. O. (2019). 
Psychosocial strategies, debasing gender-based violence in Nigeria. Research on humanities and social sciences, 9(22), 30-32.

Othman, S., \& Adenan, N. A. M. (2008). Domestic violence management in Malaysia: A survey on the primary health care providers. Asia Pacific family medicine, 7(1), 2. https://doi.org/10.1186/1447-056X-7-2

Peterman, A., Potts, A., \& O'Donnell, M. et al. (2020). Pandemics and Violence Against Women and Children. Center for Global Development Working Paper 528. Washington, DC: Centre for Global Development. https//www.cgdev.org/publication/pandemics-and-violence-against-women-and-children.

Poate, S. (2020). 75\% increase in domestic violence searches since Coronavirus. NBN News. Retrieved on 7th September, 2020 from: https://www.nbnnews.com.au/2020/03/31/dvsearches-coronavirus/ news/uk-52157620.

Razali, S., Abd Razak, S. N. F., Abd Halim, N. A., Anwar, F. A. M., Abd Jalil, N., Ahmad, S. B., ... Sood, M. (2018). Perception of Online Newspapers on the Coverage of Domestic Violence in Malaysia. Journal of Media and Information Warfare, 11(2), 19-45.

Reuters News Agency (2020). As domestic abuse rises in lockdown, France to fund hotel rooms. Aljazeera. Retrieved on 14th October, 2020 from: https://www.aljazeera.com/news/2020/03/domestic-abuse-rises-lockdown-france-fundhotel-r ooms-200331074110199.html.

Serrata, J. V., Rodriguez, R., Castro, J. E., \& Hernandez-Martinez, M. (2020). Well-being of Latina survivors of intimate partner violence and sexual assault receiving trauma-informed and culturally-specific services. Journal of family violence, 35(2), 169-180. https://doi.org/10.1007/s10896-019-00049-z

Tashny, S. (2020, 11 April). In Malaysia, domestic violence spikes amid lockdown to slow coronavirus infections. Retrieved from https://www.scmp.com/week-asia/people/article/

Taub, A. (2020). A new Covid-19 crisis: Domestic abuse rises worldwide. New York Times, 6.

UN News. (2020). "UN chief calls for domestic violence 'ceasefire' amid 'horrifying global surge'”. Retrieved on 14th October, 2020 from [Online]. <https://news.un.org/en/story/2020/04/1061052> on: 01/09/2020)

Usher, K., Bhullar, N., Durkin, J., Gyamfi, N., \& Jackson, D. (2020). Family violence and COVID-19: Increased vulnerability and reduced options for support. International journal of mental health nursing. https://doi.org/10.1111/inm.12735

van Gelder, N., Peterman, A., Potts, A., O’Donnell, M., Thompson, K., Shah, N., \& Oertelt-Prigione, S. (2020). COVID-19: Reducing the risk of infection might increase the risk of intimate partner violence. eClinical Medicine. https://doi.org/10.1016/j.eclinm.2020.100348 
Wagers, S. (2020). Domestic violence growing in wake of coronavirus outbreak. The Conversation. Retrieved on $10^{\text {th }}$ April, 2020 from: https://theconversation.com/domestic-violence-growing-in-wake-of-coronavirus-outbreak-13 5598.

Women's Centre for Change (2019). Surviving Court: A Guide to Understanding Criminal Court Process Penang, Malaysia.

\section{Copyright Disclaimer}

Copyright for this article is retained by the author(s), with first publication rights granted to the journal.

This is an open-access article distributed under the terms and conditions of the Creative Commons Attribution license (http://creativecommons.org/licenses/by/4.0/). 